\title{
Tindak Tutur Direktif Dalam Pidato Wakil Gubernur Nusa Tenggara Barat Dalam Penanganan Penyebaran Virus Korona-19
}

\author{
Sri Agustian Lestari ${ }^{1}$, Sukri $^{2}$, Burhanuddin ${ }^{3}$ \\ ${ }^{1}$ Magister Pendidikan Bahasa Indonesia FKIP Universitas Mataram \\ ${ }^{23}$ Universitas Mataram, \\ Email: hendrasri675@gmail.com, burhanuddin.fkip@unram.ac.id, sukri1@unram.ac.id
}

\begin{abstract}
Abstrak. Penelitian ini bertujuan untuk menjelaskan jenis tindak tutur direktif dan kecenderungan penggunaan jenis tindak tutur direktif dalam pidato wakil gubernur NTB terkait penanganan virus corona19. Secara metodologis penelitian ini menggunakan metode simak, sedangkan analisis data menggunakan metode padan ekstralingual. Hasil penelitian ini terdapat 6 jenis tindak tutur direktif yaitu; tindak tutur direktif permintaan yang ditandai dengan kata minta, mari dan harapkan. Tindak tutur direktif bertanya ditandai dengan kata tanya bagaimana. Tindak tutur direktif perintah ditandai dengan kata tetap, ingat, partikel-lah, penggunaan tanda seru, dan kata harus. tindak tutur direktif larangan ditandai dengan kata jangan dan frase tidak boleh. Tindak tutur direktif pemberian izin ditandai dengan frase akan didenda. tindak tutur direktif nasehat ditandai dengan kata kalau, maka, jika, dan frase paling efektif, sangat penting. Keenam jenis tindak tutur direktif yang digunakan dalam pidato wakil gubernur NTB terkait penanganan virus covid-19 terdapat kecenderungan penggunaan tindak tutur direktif permintaan, perintah dan nasehat, akan tetapi yang paling dominan digunakan adalah tidak tutur direktif jenis nasehat.
\end{abstract}

\section{Kata kunci: Pragmatik, Tindak Tutur, Tindak Tutur Direktif}

\section{PENDAHULUAN}

Mengingat esensi bahasa yang sedemikian penting dalam kehidupan masyarakat atau lebih jelasnya peran penting menjalankan segala aktivitas sehari-hari, tentu setiap anggota individu dalam kehidupan sosial masyarakat selalu terlibat dalam komunikasi, baik bertindak sebagai komunikator (pembicara) maupun sebagai komunikan (penyimak). Dengan demikian, bahasa digunakan sebagai alat komunikasi untuk menyampaikan pesan atau maksud pembicara kepada pendengar. Ketika berkomunikasi setiap tuturan adalah ujaran. Nuramila (2020:1) menyatakan bahwa komunikasi merupakan serangkaian tindak tutur yang digunakan secara bersistem untuk mencapai tujuan tertentu. Pasca resmi dilantik di Istana Negara, Jakarta, pada Rabu tanggal 19 September 2018, lalu bertugas menjalankan amanahnya sebagai Wakil Gubernur Provinsi Nusa Tenggara Barat (NTB), maka figur seorang Siti Rohmi Djalillah bukan lagi dilihat sebagai orang secara pribadi melainkan dipandang sebagai figur wakil pemimpin kepala daerah yang memiliki "kebijakan" atas seluruh masyarakat yang dipimpinnya. Tentu saja, sebagai seorang wakil gubernur, apa yang diungkapkan Siti Rohmi Djalillah tidak hanya mencitrakan dirinya sebagai individu biasa (masyarakat) tetapi juga mencitrakan sekaligus merepresentasikan bahwa dirinya adalah seorang wakil pemimpin (kepala daerah, wakil gubernur).

Dalam kapasitas sebagai wakil gubernur, apa saja yang diungkapkannya, baik saat mengikuti suatu kegiatan, acara, saat menghadapi situasi dan kondisi tertentu yang sedang terjadi di daerah, dapat menimbulkan sesuatu yang berdampak terhadap masyarakat. Dengan kata lain, baik pernyataan, ungkapan gubernur bagi masyarakat (pendengar), terkait situasi dan kondisi pengucapan kalimat terhadap respon masyarakat yang tentu berhubungan dengan stabilitas kehidupan.

Belum dua tahun masa pemerintahan Dr. H. Zulkieflimansyah dan wakilnya Siti Rohmi Djalillah, berbagai persoalan penting muncul. Hal ini mengharuskan pemerintah untuk cepat merespon fenomena yang terjadi. Sejumlah persoalan-persoalan tersebut antara lain misalnya keresahan masyarakat menghadapi bencana covid-19. Tidak hanya terbatas pada persoalan penyakit atau virus yang dihadapi itu, tetapi juga menyangkut 
dampak yang ditimbulkan terhadap berbagai bidang seperti sosial, agama, ekonomi dan pendidikan sebagai akibat dari ditetapkannya berbagai kebijakan yang memang menjadi tuntutan pemerintahan pusat kepada masyarakat serta respon mental masyarakat menilai adanya virus covid-19.

Berkaitan dengan hal di atas, maka permasalahan yang tengah dihadapi sangat berpengaruh terhadap respon pemerintah yang terepresentasi melalui tindak tutur direktif yang notabennya memiliki dimensi penanganan. Sangatlah penting untuk meneliti kecenderungan jenis tindak tutur direktif yang digunakan oleh Wakil Gubernur NTB, karena bebrapa penggunaan tuturan direktif akan berbeda-beda keefektivannya dalam penanganan virus covid-19 tergantung kepada jenis direktif tersebut. Sebagai contoh ketika Wakil Gubernur menuturkan ujaran direktif memerintahkan tentu akan berbeda respon mitra tutur dengan ketika Wakil Gubernur NTB menuturkan ujaran saran atau permintaan. Ketika Wakil Gubernur NTB menuturkan ujaran direktif memerintah maka petutur tidak memeiliki pilihan lain selain melaksanakan mekna tuturan tersebut. Beda halnya dengan ketika Wakil Gubernur menuturkan ujaran direktif saran atau permintaan maka petutur memiliki pilihan akan setuju atau tidak dengan makna tuturan tersebut. Maka di sinilah letak peran strategi tindak tutur direktif menjadi sangat dibutuhkan.

Ibrahim (1993:32) mendefinisikan tindak tutur direktif adalah tindak tutur yang mengekspresikan sikap penutur terhadap tindakan yang akan dilakukan oleh mitra tutur. Artinya sikap penutur tergantung terhadap tindakan yang akan dilakukan oleh mitra tutur.

Yule (1996 :93) mendefinisikan tindak tutur direktif merupakan jenis tindak tutur yang dipakai oleh penutur untuk menyuruh orang lain melakukan sesuatu. Menurutnya tindak tutur jenis ini menyatakan apa yang terjadi dengan keinginan penutur atau mitra tutur. Menurut Yule tindak tutur yang masuk jenis ini adalah tindak tutur merintah, permohonan, pemesanan, pemberian saran.
Masa covid-19 seperti saat-saat ini, terdapat banyak tuturan-tuturan terutama dibawah pimpinan wakil Gubernur NTB dalam menangani penyebaran virus tersebut. Oleh karena iu peran pemimpin semakin dibutuhkan, sehingga semakin banyak tindak tutur direktif yang muncul dalam tuturan wakil gubernur. Salah satu contoh tindak tutur direktif yang muncul pada pidato Wakil Gubernur NTB di Ruang Rapat Utama (RUU), Kantor Gubernur NTB, Rabu 15 Juli 2020. Tugas kita membuat masyarakat paham. Jangan sampai, ada masyarakat yang menganggap covid-19 ini tidak ada. Ungkapan tindak tutur tersebut termasuk dalam tindak tutur direktif perintah, digolongkan ke dalam tindak tutur direktif perintah karena terdapat ujaran Tugas kita membuat masyarakat paham yang artinya wagub memerintahkan kepada semua anggota rapat untuk menjalankan tugas yakni membuat masyarakat paham bahwa virus covid-19 tersebut benar adanya oleh karena itu masyarakat harus benar-benar sadar bagaimana cara untuk melindungi diri dari terpapar virus covid-19.

Contoh tindak tutur direktif berupa saran juga digunakan oleh Wagub NTB dalam pidatonya di tempat yang sama yakni ia menuturkan bahwa Saya rasa, menjalankan protokol kesehatan ini tidak terlalu susah, masker harganya cukup terjangkau, bahkan banyak dibagikan oleh pemerintah. Tidak hanya itu, menjaga jarak dan mencuci tangan juga gratis, intinya kita semua ada kemauan. Ungkapan tindak tutur tersebut termasuk dalam tindak tutur direktif berupa saran, digolongkan ke dalam tindak tutur direktif saran karena terdapat ujaran saya rasa dan ujaran intinya yang artinya ujaran tersebut bahwa wagub menyarankan kepada semua anggota rapat bahwa menurut hemat beliau selaku wagub Ia menyarankan selama masyarakat memiliki kemauan sangatlah mudah untuk menjalankan protokol kesehatan.

Tuturan direktif permintaan juga digunakan oleh wagub dalam pidatonya tersebut di tempat yang sama pula yakni Ia menuturkan Bantu tenaga kesehatan kita. 
Kasihanilah mereka, mereka rela jauh dari keluarga, setengah mati berjuang memakai APD. Itu semua dilakukan demi kesehatan kita semua. Ungkapan tindak tutur tersebut termasuk dalam tindak tutur direktif berupa permintaan, digolongkan ke dalam tindak tutur direktif permintaan karena terdapat ujaran Bantu tenaga kesehatan kita yang artinya wagub dengan kalimat yang menyentuh meminta kepada masyarakat untuk membantu petugas kesehatan untuk bersama-sama melawan penyebaran virus covid-19 dengan cara bersama mematuhi protokol kesehatan.

\section{KAJIAN PUSTAKA}

Sebagai bahan rujukan, penulis mengacu kepada beberapa penelitian terdahulu mengenai tindak tutur, yaitu Muhartoyo (2013); Burhanudin dan Sumarlam (2015a dan 2015b); Maryam (2015); Saddhono dan Fatma (2016); Fitriah dan Fitriani (2017); Islam (2017); Yayuk (2018); Hutahean (2018); Sagita (2019); Badelah, Mahsun, dan Burhanuddin (2019); serta Prawita dan Utomo (2020). Muhartoyo (2013) menjelaskan tentang jenis dan kecenderungan pemakaian tindak tutur direktif yang terdapat di film Sleeping Beauty. Burhanuddin dan Sumarlam (2015a) menjelaskan strategi (jenis dan stategi dominan) kesopanan berbahasa yang digunakan Presiden Joko Widodo dalam merespon persoalan sosial politik bangsa. Penelitian Burhanuddin dan Sumarlam (2015b) menjelaskan kategori tindak tutur imperatif dalam tabloid Suara Muhammadiyah (SM) serta jenis imperatif dominan dari perfektif teori Rahadi (2000). Maryam (2015) menjelaskan tindak tutur, kesantunan yang muncul dalam sidang DPRD Lombok Barat serta kaitannya dengan dengan pembelajaran di SMA. Saddhono dan Fatma (2016) menjelaskan bentuk, fungsi, dan tipikal bahasa daerah dalam tindak tutur direktif di perguruan tinggi di Sulawesi tengah. Fitriah dan Fitriani (2017) menjelaskan makna tindak tutur ilokusi, maksud tindak tutur ilokusi dan perlokusi, jenis konteks tuturan, dan cara penyampaian tindak tutur lokusi, ilokusi dan perlokusi yang terdapat dalam novel Marwah di Ujung Bara Karya R.H. Firtiadi. Islam (2017) mendeskripsikan tindak tutur ilokusi dalam wawancara Gubernur Nusa Tenggara Barat dalam Talkshow "MATA NAJWA". Hutahaean (2018) mendeskripsikan jenis tindak tutur yang terdapat pada pidato Presiden Jokowi. Yayuk (2018) mendeskripsikan wujud dan klasifikasi fungsi tindak tutur pada teks Indonesia Raya karya W.R.Supratman. Sagita (2019) mendeskripsikan bentuk tindak tutur ilokusi dan jenis tindak tutur ilokusi di CNN Indonesia. Badelah, Mahsun, dan Burhanuddin. (2019) menjelaskan tentang Tindak Tutur Kesantunan Guru dan Siswa dalam Pembelajaran Bahasa Indonesia di SMP Negeri 2 Sakra: Tinjauan Pragmatik. Adapun penelitian Prawita dan Utomo (2020) bertujuan mendeskripsikan fungsi tindak tutur direktif yang terdapat dalam saluran youtube Mata Najwa dengan judul "Gara-Gara Corona Mengapa Indonesia Tidak Seperti Singapura".

\section{METODE PENELITIAN}

Sumber data utama penelitian ini adalah pidato pidato Wakil Gubernur Siti Rohmi Djalillah terkait penganganan covid19 yang penulis unggah dari berbagai flatform media sosial seperti instagram, fanspage, faccebook dan channel Youtube. Adapun instrumen dalam penelitian ini adalah transkip ujaran pidato Wakil Gubernur Siti Rohmi Djalillah. Penelitian yang dilakukan ini memiliki wujud data berupa postinganpostingan dan rekaman vidio yang di dalamnya terdapat tuturan jenis direktif wakil gubernur NTB terkait penanganan virus corona-19. Tuturan yang ada dalam rekaman vidio dan postingan-postingan yang ada pada situs-situs tersebut akan ditranskrip ke dalam bentuk teks secara tertulis. Ada bebrapa metode yang digunkan dalam penelitian ini diantaranya adalah metode simak, kepustakaan, pengamatan dan metode dokumentasi. Metode pertama dalam penelitian ini adalah metode simak dilakukan dengan menyadap. Metode simak adalah cara yang digunakan peneliti untuk memperoleh 
data yang dilakukan dengan menyimak penggunaan bahasa (Mahsun, 2014:92). Dalam hal ini yang disimak adalah penggunaan bahasa secara lisan yang bersumber dari pidato Wakil Gubernur Siti Rohmi Djalillah ketika menangani virus covid-19. Setelah menyimak tuturan yang dituturkan oleh wakil gubernur dalam pidatonya maka peneliti perlu untuk menelaah juga beberapa tuturan wakil gubernur secara tertulis yang dimuat di akun Facebook resmi provinsi NTB yakni Humas NTB menggunakan metode kepustkaan dan dokumentasi.Selanjutnya untuk memperoleh data yang representatif dari metode simak, kepustakaan, penelaahaan dan dokumentasi maka dalam hal ini digunakan teknik lanjutan. Jadi, bentuk-bentuk tuturan yang mengandung jenis tindak tutur direktif tersebut dicatatmenggunakan teknik sadap. Maksud dari tenik sadap disini adalah menyadap penggunaan bahasa,baik secara lisan maupun tulisan. Dalam praktiknya, teknik sdap ini diikuti dengan teknk lanjutan, yaitu teknik simak libat cakap, teknik simak bebas cakap, teknik simak bebas libat cakap dan teknik cakap. Teknik lanjutan yang digunakan dalam teknik sadap di penelitian ini adalah teknik simak bebas libat cakap dan teknik catat. Teknik bebas libat cakap adalah penelitian yang tidak melibatkan peneliti secara langsung dalam penggunaan bahasa, peneliti hanya berperan sebagai pengamat penggunaan bahasa oleh para informannya. Setelah itu peneliti juga menggunakan teknik catat. Jadi teknik bebas libat cakap dan teknik catat ini digunakan untuk mengambil data berupa vidio rekaman, dokumen tertulis yang tersedia di media sosial tentang penanggulangan virus covid-19.

\section{HASIL PENELITIAN DAN PEMBAHASAN}

Berdasarkan hasil penemuan bentuk tindak tutur direktif dalam pidato Wakil Gubernur NTB terkait penanganan virus corona-19, ditemukan enam jenis tindak tutur direktif yaitu permintaan, pertanyaan, perintah, larangan, pemberian izin, dan nasihat. Berikut dikemukakan tentang temuan penelitian tersebut.

\section{Tindak Tutur Direktif Jenis Permintaan}

Berdasarkan proses penganaalisisan data ditemukan bebrapa data tentang pemakaian tindak tutur direktif permintaan, yang diuraikan sebagai berikut.

a1. Bagi para finalis, saya harapkan untuk tetap mengkampanyekan pentingnya penerapan protocol kesehatan dalam upaya melawan pandemi Covid 19.

b1. Mari perkuat sinergi, kita berjuang bersama dalam melayani masyarakat.

c1. Kami meminta kepada tenaga kesehatan untuk tidak jenuh dalam melayani pasien yang terpapar oleh virus Covid 19, hal ini sebagai bentuk pengabdian kepada masyarakat.

Peristiwa tutur pada data a1 dapat dipahami bahwa data tersebut termasuk jenis tindak tutur direktif permintan yang di tandai dengan kata harapkan, berharap, diharapkan, harapan, minta, meminta, dan mari. Masingmasing kata tersebut secara langsung bermakna meminta terhadap sesuatu hal dalam setiap kalimat pada masing-masing data.

Contoh data yang dapat mewakili keseluruhan data tindak tutur direktif jenis permintaan yaitu data a1. " Bagi para finalis, saya harpkan untk tetap mengkampanyekan pentingnya penerapan protokol kesehatan dalam upaya melawan pandemi Covid- '19". Berdasarkan kalimat tersebut kata 'harapkan' bermakna memohon, meminta, dan hendaklah. oleh karena itu, secara directif speech kata 'harapkan' dalam kalimat tersebut bermakna penutur meminta kepada petutur untuk tetap menerapkan protokol kesehatan. hal tersebut dapat dikatakan demikian karena dalam kalimat, kata 'harapkan' memiliki hubungan makna dengan kata 'tetap' dan 'mengkampanyekan'. Kata tetap sebagai sikap konsisten atas pemintaan penutur sebagai tindakan yang akan dilakukan oleh petutur. Permitaan ini terkait situasi penutur dan petutur dalam kondisi melawan pandemi Covid-19, maka petutur diminta untuk 
melakukan suatu tindakan seperti dalam kalimat 'menerapkan protokol kesehatan' sebagai bentuk kampanye penutur dan petutur.

Analisis ini juga berlaku untuk data yang diklasiikasikan dalam tindak tutur direktif permintaan, dengan memperhatikan kata yag mengindikasikan jenis permintaan seperti data b1 dan c1. indikasi kata yang berbeda dengan kata 'diharapkan' namun termasuk ke jenis tindak tutur direkif permintaan seperti kata 'minta' dan 'mari'. Dua kata tersebut memiliki makna yang berbeda dengan kata harap. Akan tetapi, kata minta dan mari sama-sama mengindikasikan indak tutur direktif jenis permintaan. kata minta memiliki makna yang jelas merujuk ke jenis direktif permintaan, sedangkan kata mari memiliki makna ajakan dan sering menandai kalimat ajakan. akan tetapi, pada data ini kata mari mengindikasikan kalimat direktif jenis permintaan. kata mari dalam kalimat $\mathrm{c} 1$, penutur mengajak petutur untuk bersinergi yang kata tersebut ada hubungannya dengan anak kalimat' kita berjuang bersama'. hal tersebut disebabkan karena antara induk dan anak kalimat memiliki makna yang berhubungan pada anak kalimat yakni frase 'berjuang bersama' yang meruoakan ajakan ajakan sekaligus permintaan penutur kepada petutur.

Berdasarkan hasil pengumpulan data, ditemukan data-data tentang pemakaian tindak tutur direktif jenis pertanyaan sebagai berikut.

d1. Salah satu tugas berat kita adalah bagaimana caranya agar masyarakat NTB sadar dan mengakui virus ini ada.

d2. Harus kita pikirkan bersama bagaimana caranya kesadaran masyarakat itu tumbuh, mau memiliki responsibility untuk menyelamatkan dirinya, keluarganya dan orang-orang disekitarnya, sebenarnya itu yang paling penting dalam penanaganan virus ini.

Peristiwa tutur pada data $\mathrm{d} 1$ dan $\mathrm{d} 2$ dapat dipahami bahwa data tersebut termasuk jenis tindak tutur direktif pertanyaan yang di tandai dengan kata tanya pada data ini ialah kata bagaimana. Kata tersebut secara langsung bermakna bertanya terhadap sesuatu hal dalam setiap kalimat pada masing-masing data.

Contoh data yang dapat mewakili keseluruhan data tindak tutur direktif jenis permintaan yaitu data d1. "Salah satu tugas berat kita adalah bagaimana caranya agar masyarakat NTB sadar dan mengakui virus ini ada". Berdasarkan kalimat tersebut kata 'bagaimana' bermakna menanyakan cara. Oleh karena itu, secara directif speech kata 'bagaimana' dalam kalimat tersebut bermakna penutur bertanya kepada petutur bagaimana caranya agar masyarakat NTB sadar dan mengakui virus ini ada. Hal tersebut dapat dikatakan demikian karena dalam kalimat, kata 'bagaimna' memiliki hubungan makna dengan kata 'sadar'. Kata 'sadar' bermakna 'insaf, tahu, dan mengerti' yang dalam konteksnya kalimat tersebut bermaksud penutur menanyakan kepada petutur bagaimana cara agar masyarakat sadar untuk mengarahkan sikap sekaligus mengerti terhadap pentingnya melindungi diri dari terpapar virus corona-19. Pertanyaan ini terkait situasi penutur dan petutur dalam kondisi melawan pandemi Covid-19, maka petutur diminta untuk melakukan suatu tindakan seperti dalam kalimat 'sadar dan mengakui virus ini ada ' sebagai bentuk kampanye penutur dan petutur dalam mencegah penyearan virus corona-19.

Berdasarkan hasil pengumpulan data, ditemukan data-data tentang pemakaian tindak tutur direktif jenis perintah sebagai berikut.

e1. ... dan kita semua dalam kondisi apapun tetap layani masyarakat dengan sebaikbaiknya

f1. Ingat, masyarakat yang berniat mendaki untu tetap menerapkan protocol kesehatan untu menghindari penularan Covid 19 di kalangan pendaki

g1. Jadikanlah rumah tempat edukasi dan bermain yang aman bagi anak, sehingga anak kita betul terlindungi. Sehingga yang terpenting kita satukan mindset dan lawan! 
h1. Di masa-masa yang sulit ini, kita harus saling bahu membah, dengan begitu seberat apapun masalah kita, bisa kita selesaikan bersama.

Peristiwa tutur pada data e1, f1, g1 dan h1 dapat dipahami bahwa data tersebut termasuk jenis tindak tutur direktif perintah yang di tandai dengan kata 'tetap', 'ingat', 'jadikanlah', '!', dan 'harus'. Masing-masing kata tersebut secara langsung bermakna memerintahkan terhadap sesuatu hal dalam setiap kalimat pada masing-masing data.

Contoh data yang dapat mewakili keseluruhan data tindak tutur direktif jenis perintah yaitu data e1. "...dan kita semua dalam kondisi apapun tetap layani masyarakat dengan sebaik-baiknya". Berdasarkan kalimat tersebut kata 'tetap' bermakna selalu berada di tempat, tidak berubah, tidak berpindah. oleh karena itu, secara directif speech kata 'tetap' dalam kalimat tersebut bermakna penutur memerintahkan kepada petutur untuk tetap memberikan pelayanan yang terbaik bagi masyarakat. Hal tersebut dapat dikatakan demikian karena dalam kalimat, kata 'tetap' memiliki hubungan makna dengan kata 'layani' dan 'sebaik-baiknya'. Kata 'layani' sebagai sikap penanganan yang diperintahkan penutur dan akan dilakukan oleh petutur. Perintah ini terkait situasi penutur dan petutur dalam kondisi melawan pandemi Covid-19, maka petutur diperintahkan untuk melakukan suatu tindakan seperti dalam kalimat 'layani masyarakat dengan sebaik-baiknya' sebagai bentuk kampanye penutur dan petutur.

Analisis ini juga berlaku untuk data yang diklasiikasikan dalam tindak tutur direktif perintah, dengan memperhatikan kata yag mengindikasikan jenis perintah seperti data f1,g1 dan h1. Indikasi kata yang berbeda dengan kata 'tetap' namun termasuk ke jenis tindak tutur direkif permintaan seperti kata 'ingat', 'jadikanlah', pemberian tanda seru, dan 'harus'. Tiga kata tersebut memiliki makna yang berbeda dengan kata harap. Akan tetapi, kata 'ingat', 'jadikanlah', penggunaan tanda baca seru, dan 'harus' sama-sama mengindikasikan indak tutur direktif jenis perintah. Kata 'ingat' bermakna perintah untuk tidak melupakan sesuatu hal. sedangkan kata 'jadikanlah' dan penggunaan tanda baca seru memiliki makna yang jelas merujuk ke jenis direktif perintah karena tanda baca seru dan partikel -lah dalam kata 'jadikanlah' merupakan tanda bahwa kalimat tersebut adalah kalimat perintah. Sedangkan kata 'harus' memiliki makna patut, wajib, mesti, dan tidak boleh tidak. Pada data ini kata 'harus' mengindikasikan kalimat direktif jenis perintah, karena dalam hubungan antar kata pada kaliat tersebut kata 'harus' memiliki makna bahwa penutur memerintahkan petutur untuk wajib atau tidak boleh tidak untuk saling bahu membahu agar pandemi bisa dilewati bersama.

Berdasarkan hasil pengumpulan data, ditemukan data-data tentang pemakaian tindak tutur direktif jenis larangan sebagai berikut.

i1. Jangan lupa, kalau kita terpaksa keluar maka wajib kita menggunkan masker, dengan begitu kita melindungi diri kita danorang lain.

j1. Kita tidak boleh bosan dengan protocol kesehatan, kita tidak bisa memilih salah satunya apakah aman atau produktif, harus keduanya.

Peristiwa tutur pada data i1 dan j1 dapat dipahami bahwa data tersebut termasuk jenis tindak tutur direktif larangan yang di tandai dengan kata 'jangan lupa' dan 'tidak boleh'. Masing-masing kata tersebut secara langsung bermakna larangan terhadap sesuatu hal dalam setiap kalimat pada masing-masing data.

Contoh data yang dapat mewakili keseluruhan data tindak tutur direktif jenis larangan yaitu data i1. "Jangan lupa, kalau kita terpaksa keluar maka wajib kita menggunkan masker, dengan begitu kita melindungi diri kita dan orang lain". Berdasarkan kalimat tersebut kata 'jangan lupa' bermakna melarang untuk lupa yang berarti tidak boleh lupa. Oleh karena itu, secara directif speech kata 'jangan lupa' dalam kalimat tersebut bermakna penutur meminta kepada petutur untuk jangan lupa menerapkan 
protokol kesehatan dengan cara menggunakan masker jikalau terpaksa harus keluar rumah. Hal tersebut dapat dikatakan demikian karena dalam kalimat, kata 'jangan lupa' memiliki hubungan makna dengan kata 'wajib' dan ' menggunakan masker'. Kata 'wajib' sebagai sikap konsisten atas larangan penutur sebagai tindakan yang akan dilakukan oleh petutur. Larangan ini terkait situasi penutur dan petutur dalam kondisi melawan pandemi Covid-19, maka petutur diminta untuk melakukan suatu tindakan seperti dalam kalimat 'wajib menggunakan masker' sebagai bentuk kampanye penutur dan petutur.

Analisis ini juga berlaku untuk data yang diklasiikasikan dalam tindak tutur direktif larangan, dengan memperhatikan kata yag mengindikasikan jenis larangan seperti data $\mathrm{j} 1$. Indikasi kata yang berbeda dengan kata 'jangan lupa' namun termasuk ke jenis tindak tutur direkif larangan seperti kata 'tidak boleh'. Kata tersebut memiliki makna yang berbeda dengan kata 'jangan lupa'. Akan tetapi, kata 'tidak boleh' sama-sama mengindikasikan indak tutur direktif jenis larangan. Kata 'tidak boleh' memiliki makna yang jelas merujuk ke jenis direktif larangan. kata 'tidak boleh' dalam kalimat j1 bermakna penutur melarang petutur untuk jangan bosan menerapkan protokol kesehatan sebagai bentuk penanganan dalam situasi tutur yakni masa pandemi.

Berdasarkan hasil pengumpulan data, ditemukan data-data tentang pemakaian tindak tutur direktif jenis pemberian izin sebagai berikut.

k1. Kita tegas, ikhtiar terus kita lakukan, kalau masih ada yang tidak patuh, akan didenda. Bismillah inshaaallah ini yang terbaik.

11. Untuk itulah kita keluarkan perda, perda ini kita tidak main-main, 14 September besok mulai penerapan denda.

Peristiwa tutur pada data $\mathrm{k} 1$ dapat dipahami bahwa data tersebut termasuk jenis tindak tutur direktif pemberian izin yang di tandai dengan frase 'akan didenda'. Frase tersebut secara langsung bermakna pemberian izin terhadap sesuatu hal dalam kalimat $\mathrm{k} 1$ yakni pemberian izin untuk penerapan hukuman.

Contoh data yang dapat mewakili keseluruhan data tindak tutur direktif jenis pemberian izin yaitu data k1. " Kita tegas, ikhtiar terus kita lakukan, kalau masih ada yang tidak patuh, akan didenda. Bismillah inshaaallah ini yang terbaik. ". Berdasarkan kalimat tersebut kata 'akan didenda' bermakna pemberian izin menerapkan. oleh karena itu, secara directif speech kata 'akan didenda' dalam kalimat tersebut bermakna penutur memberikan izin kepada petutur untuk menerapkan hukuman denda. Hal tersebut dapat dikatakan demikian karena dalam kalimat, kata 'akan didenda' memiliki hubungan makna dengan klausa 'kalau masih ada yang tidak patuh'. Klausa tersebut sebagai sikap tegas atas pemberian izin penutur sebagai tindakan yang akan dilakukan oleh petutur. Pemberian izin ini terkait situasi penutur dan petutur dalam kondisi melawan pandemi Covid-19, maka petutur diberikan izin untuk melakukan suatu tindakan seperti dalam kalimat 'akan didenda' sebagai bentuk penanganan penebaran virus corona-19.

Analisis ini juga berlaku untuk data yang diklasiikasikan dalam tindak tutur direktif pemberian izin, dengan memperhatikan kata yang mengindikasikan jenis pemberian izin seperti data 11. indikasi kata yang berbeda dengan kata 'akan didenda' namun termasuk ke jenis tindak tutur direkif permintaan seperti kata 'mulai'. Kata tersebut memiliki makna yang berbeda dengan kata 'akan'. Akan tetapi, kata 'akan' sama-sama mengindikasikan indak tutur direktif jenis pemberian izin.

Berdasarkan hasil pengumpulan data, ditemukan data-data tentang pemakaian tindak tutur direktif jenis nasehat sebagai berikut.

ml. Kewaspadaan merupakan langkah awal paling efektif dalam menangkal penularan dan penyebaran pandemi Covid 19. 
n1. Tentunya di dalam menangani pandemic Covid 19 ini memang tidak mungkin bisa satu pihak saja yang bekerja, sinegritas itu memang sangat penting dan ini terbukti dengan sinergi kita semua pihak.

o1. Kalau kita pegang prinsip ini semua, inshaalah kita akan bisa hadapi pandemi ini, melalui pandemi ini dengan baik.

p1. Inshaalah kalau kita disiplin, sabar menerapkan protocol Covid-19 ini, maka kita akan bisa hidup produktif dalam masa sulit ini.

q1. Saya ingatkan kepada tenaga kesehatan untuk tetap berikhtiar semaksimal mungkin dalam memberikan pelayanan terhadap masyarakat.

r1. Kuncinya adalah patuhi protocol Covid 19 dan semoga kita bisa menjadi contoh bagi masyarakat, melihat cotoh daripada pemimpinnya ...

s1. Kita sebagai orang tua di masa pandemi ini dituntut berikhtiar lebih menjaga anak kita... jadikanlah rumah tempat edukasi dan bermain yang aman bagi anak, sehingga anak kita betul terlindungi.

t1. Perda tentang penanggunalangan penyakit menular bukan untuk menyakiti masyarakat. tetapi itu semua dilakukan agar kita semua terjaga dari ganasnya Covid 19.

Peristiwa tutur pada data $\mathrm{m} 1, \mathrm{n} 1, \mathrm{o} 1, \mathrm{p} 1, \mathrm{q} 1, \mathrm{r} 1, \mathrm{~s} 1$ dan $\mathrm{t} 1$ dapat dipahami bahwa data tersebut termasuk jenis tindak tutur direktif nasehat yang di tandai dengan kata 'paling efektif', 'sangat penting', 'kalau', 'maka', 'ingatkan', 'kuncinya', 'sehingga' dan 'agar'. Masing-masing kata tersebut secara langsung bermakna menasehati terhadap sesuatu hal dalam setiap kalimat pada masingmasing data.

Contoh data yang dapat mewakili keseluruhan data tindak tutur direktif jenis permintaan yaitu data m1. " Kewaspadaan merupakan langkah awal paling efektif dalam menangkal penularan dan penyebaran pandemi Covid 19". Berdasarkan kalimat tersebut frase 'paling efektif' bermakna sangat berguna, sangat manjur, sangat berhasil. oleh karena itu, secara directif speech frase 'paling efektif' dalam kalimat tersebut bermakna penutur menasehati petutur untuk tetap waspada dalam menangkal penyebaran virus corona-19 karena dengan tetap waspada hal tersebut paling efektif untuk menekan laju penularan virus. Hal tersebut dapat dikatakan demikian karena dalam kalimat, kata 'paling efektif' memiliki hubungan makna dengan kata 'menangkal'. Kata 'menangkal' sebagai harapan penutur dan petutur atas kalimat nasehat yang dituturkan oleh penutur. Nasehat ini terkait situasi penutur dan petutur dalam kondisi melawan pandemi Covid-19, maka petutur diminta untuk melakukan suatu tindakan seperti dalam kalimat 'kewaspadaan merupakan langkah awal paling efektif' sebagai bentuk kampanye penutur dan petutur untuk menankal peyebaran virus corona-19.

Analisis ini juga berlaku untuk data yang diklasiikasikan dalam tindak tutur direktif permintaan, dengan memperhatikan kata yag mengindikasikan jenis permintaan seperti data $\mathrm{n} 1, \mathrm{o} 1, \mathrm{p} 1, \mathrm{q} 1, \mathrm{r} 1, \mathrm{~s} 1$ dan $\mathrm{t} 1$. indikasi kata yang berbeda dengan frase 'paling efektif' namun termasuk ke jenis tindak tutur direkif permintaan seperti kata 'sangat penting', 'kalau', 'maka', 'ingatkan', 'kuncinya', 'sehingga' dan 'agar'. Beberapa kata tersebut memiliki makna yang berbeda dengan kata 'paling efektif'. Akan tetapi, kata 'sangat penting', 'kalau', 'maka', 'ingatkan', 'kuncinya', 'sehingga' dan 'agar' sama-sama mengindikasikan tindak tutur direktif jenis nasehat. frase 'sangat penting' memiliki makna paling utama atau paling perlu yang jelas merujuk ke jenis direktif nasehat, sedangkan kata 'kalau' ialah kata hubung untuk menandai syarat akan tetapi, pada data ini kata 'kalau' mengindikasikan kalimat direktif jenis nasehat, karena kata tersebut berhubungan dengan kata setelahnya yaitu kata 'maka'. Kata 'kalau' dalam kalimat p1, penutur menasehati petutur untuk disiplin menerapkan protokol kesehatan yang kata tersebut ada hubungannya dengan anak kalimat' maka kita akan bisa hidup produktif dalam masa sulit ini'. sehingga dalam konteks tuturnya kalimat tersebut digolongkan ke dalam direktif nasehat. Hal tersebut 
disebabkan karena antara induk dan anak kalimat memiliki makna yang berhubungan pada anak kalimat yakni frase 'maka kita akan bisa' yang merupakan keinginan bersama antara penutur dan petutur apabila petutur mengikuti maksud dari kalimat direktif nasehat tersebut.

\section{Kecenderungan Penggunaan Tindak Tutur Direktif}

Berdasarkan hasil analisis mengenai jenis tindak tutur direktif dalam pidato wakil gubernur NTB terkait penanganan virus covid-19, ditemukan 6 jenis tindak tutur direktif yaitu permintaan, pertanyaan, perintah, nasehat, pemberian izin dan larangan. berikut merupakan tabel hasil yang ditemukan kecenderungan penggunaan tindak tutur direktif dalam pidato wakil gubernur NTB terkait penanganan virus covid-19.

Tabel 1. Kecenderungan Pemakaian Tindak Tutur Direktif

\begin{tabular}{llcc}
\hline No. & $\begin{array}{c}\text { Jenis } \\
\text { Tindak } \\
\text { Tutur }\end{array}$ & $\begin{array}{c}\text { Jumlah } \\
\text { Tindak } \\
\text { Tutur }\end{array}$ & $\begin{array}{c}\text { Kencendrungan } \\
\text { Pemakaian (\%) }\end{array}$ \\
\hline 1. & Permintaan & 13 & 17,3 \\
2. & Pertanyaan & 5 & 6,6 \\
3. & Perintah & 20 & 26,6 \\
4. & Larangan & 11 & 14,6 \\
5. & Pemberian & 2 & 2,6 \\
& izin & & 29,3 \\
6. & Nasehat & 22 & $\mathbf{9 7}$ \\
\hline \multicolumn{2}{r}{ Jumlah } & & \\
\hline \multicolumn{7}{r}{}
\end{tabular}

\section{Berdasarkan}

pemaparan

kecenderungan penggunaan tindak tutur direktif dalam tabel persentase penggunaan tindak tutur direktif sesuai jenis masingmasing di atas menunjukkan bahwa tindak tutur direktif permintaan dengan persentase $17,3 \%$, kedua tindak tutur direktif pertanyaan dengan persentase $6,6 \%$, ketiga tindak tutur direktif perintah $26,6 \%$, keempat tindak tutur direktif larangan 14,6\%, kelima tindak tutur direktif pemberian izin dengan persentase 2,6\%, dan terakhir tindak tutur nasehat dengan persentase 29,3\%. Dari beberapa jenis tindak tutur yang muncul dalam pidato wakil gubernur NTB terkait penanganan virus covid-19 tersebut dapat disimpulkan bahwa tindak tutur direktif permintaan, nasehat dan perintah merupakan jenis tindak tutur direktif yang paling sering digunakan, akan tetapi tindak tutur nasehat mendominasi ketiga jenis tidak tutur yang sering digunakan dalam pidato wakil gubernur NTB terkait penaganan virus covid-19 tersebut.

\section{SIMPULAN}

Simpulan penggunaan tindak tutur direktif sering digunakan pada pidato wakil gubernur NTB dalam penanganan virus covid-19. Hampir dalam setiap pidato wakil gubernur NTB dalam menangani penyebaran virus covid-19 menggunakan tidak tutur direktif permintaan, larangan, perintah, pemberian izin, pertanyaan, dan nasehat. Penggunaan tindak tutur direktif menasehati, permintaan dan perintah merupakan tindak tutur direktif yang mendominasi pidato wakil gubernur NTB dalam menangani virus covid19. Hal tersebut dikatakan demikian karena tidak lepas dari konteks penutur yakni sebagai figur wakil pemimpin kepala daerah yang memiliki "kebijakan" atas seluruh masyarakat yang dipimpinnya. Tentu saja, sebagai seorang wakil gubernur, apa yang diungkapkan Siti Rohmi Djalillah tidak hanya mencitrakan dirinya sebagai individu biasa (masyarakat) tetapi juga mencitrakan sekaligus merepresentasikan bahwa dirinya adalah seorang wakil pemimpin (kepala daerah, wakil gubernur). Dalam kapasitas sebagai wakil gubernur, apa saja yang diungkapkannya, baik saat mengikuti suatu kegiatan, acara, saat menghadapi situasi dan kondisi tertentu yang sedang terjadi di daerah, dapat menimbulkan sesuatu yang berdampak terhadap masyarakat. Dengan kata lain, baik pernyataan, ungkapan gubernur bagi masyarakat (pendengar), terkait situasi dan kondisi pengucapan kalimat terhadap respon masyarakat yang tentu berhubungan dengan stabilitas kehidupan.

\section{DAFTAR PUSTAKA}

Badelah, Mahsun, dan Burhanuddin. 2019. Tindak Tutur Kesantunan Guru dan Siswa dalam Pembelajaran Bahasa Indonesia di SMP Negeri 2 Sakra: Tinjauan Pragmatik. Jurnal Lingua: 
Jurnal Bahasa, Sastra, dan Pengajarannya, 16(2). 219-234.

Burhanuddin dan Sumarlam. 2015a. Strategi

Kesopanan Berbicara Presiden

Joko Widodo: Potret Tindak Tutur

Penanganan Masalah Sosial Politik

Bangsa. Jurnal Adabiyyat, Volume $\mathrm{XIV}(2)$.

Burhanuddin dan Sumarlam. 2015b. Tindak Tutur Imperatif Khutbah Jumat dalam Tabloid Suara Muhammadiyah. Jurnal Prosiding Prasasti II, halaman 464-469.

Fitriah dan fitriani. 2017. Analisis Tindak Tutur Dalam Novel Marwah Di Ujung Bara Karya R.H. Fitriadi. JURNAL UNSYAH, volume 5: 1.

Hutahaean. 2018. Analisis Tindak Tutur Pidato Presiden Jokowi pada Apec 2014 di China. Jurnal Ilmu Budaya, volume 15:1.

Ibrahim, Abdul Syukur. 1993. Kajian Tindak Tutur. Surabaya: Usaha Nasional.

Islam. 2017. Tindak Tutur Ilokusi dalam Wawancara Tgh. Muhammad Zainul Majdi Pada Talkshow "Mata Najwa". Jurnal LINGUA. Volume 14:1.

Mahsun. 2014. Metode Penelitian Bahasa: Aneka Teknik dan Strateginya. Jakarta: Raja Grafindo.

Maryam, Siti. 2015. "Tindak Tutur dalam Sidang Dewan Perwakilan Rakyat Daerah Sebuah Kajian Pragmatik dan Relevansinya terhadap Pembelajaran Bahasa di SMA." Tesis. Mataram: Universitas Mataram.

Muhartoyo. 2013. Directive Speech Act in The Movie "Sleeping Beauty". Jurnal Humaniora, (4): 949-966.

Nuramila, 2020. Kajian Pragmatik Tindak Tutur dalam Media Sosial. Banten: Yayasan Pendidikan dan Sosial Indonesia Maju (YPSIM).

Prawita dan Utomo. 2020. Analysis Of Directive Speech Act in Mata Najwa Youtube Chanel " Because Corona, Why Indonesia Is Not Like Singapore. Jurnal Aksis, (4)1.
Rustono.1999. Pokok-Pokok Pragmatik. Semarang: CV IKIP Semarang.

Saddhono, Kundharu dan Fatma. 2016. The Form and Function of Local Language in

Directive Speech Act at a University in Central Sulawesi. Jurnal Lingua Cultura, (10)1.

Sagita. 2019. Tindak Tutur Ilokusi Ridwan Kamil dalam Talkshow Insightdi $\mathrm{CNN}$ Indonesia. Jurnal Lensa, (9)2.

Yayuk. 2018. Tindak Tutur pada Teks Indonesia Raya Karya W.R. Supratman. Jurnal Metalingua, (16):(2).

Yule, George. 1996. Pragmatics. New York: Oxford University Press. 